\title{
Acute Kidney Injury due to Rhabdomyolysis
}

\author{
Mahbub $\mathrm{T}^{1}$, Jahan $\mathrm{F}^{2}$, Haque $\mathrm{DM}^{3}$, Chowdhury $\mathrm{MNU}^{4}$.
}

\begin{abstract}
Rhabdomyolysis was first described as crush syndrome, during the London blitz of world war-II. It is a common clinical syndrome resulting from muscle injury there after release of toxic cellular component especially myoglobin. Muscle injury may results from a variety of causes. Most common clinical presentation of rhabdomyolysis is triad of myalgia, weakness and dark colour urine. But presentation may be varied. Very often it causes acute kidney injury and demands renal replacement therapy. Acute Renal Failure (ARF) is usually associated with very high rise of Creatinine Kinase $(C K)>10,000 \mathrm{u} / \mathrm{L}^{1}$. In this series, there are few cases with rhabdomyolysis who were admitted and treated in Dhaka Medical College Hospital (DMCH) during July 2010 to April 2011. These cases of rhabdomyolysis normally developed acute kidney injury who were managed with dialysis support.
\end{abstract}

Key-words: Rhabdomyolysis, Creatinine Kinase, Hemodialysis, Myogloblin.

Case-1: A 54 years farmer from Jessore was referred to Dhaka Medical College in Nephrology department on 24 July 2011 with the history of multiple honey bee stinging while extracting honey, followed by rapid deterioration of his consciousness and complete cessation of urine within day. Examination revealed, patient was unconscious, Glasgow Coma Scale (GCS)-6, moderate leg oedema, BP-140/85 mmHg, bilateral coarse crepitations in lungs, innumerable number of stings all over the body and urine output was almost nil. Investigation showed serum creatinine $-9.4 \mathrm{mg} / \mathrm{dl}$, creatinine kinase-15575 u/l, serum potassium-5.5 $\mathrm{mmol} / \mathrm{l}$, serum calcium-1.8mmol/l, serum phosphate $-1.7 \mathrm{mmol} / \mathrm{l}$, urea-75 mg/dl. Haemo-dialysis (HD) was urgently introduced to save his life. The patient was improved after getting second session of HD. Though there was rapid improvement of his general condition but he remained oliguric for prolonged duration. Up to two weeks he passed only $40-50 \mathrm{ml}$ of urine per day. He received total 22 sessions of HD over one and half months until his urine output becomes normal. Later he was discharged with Serum Creatinine 1.7 $\mathrm{mg} / \mathrm{dl}$ with normal urine output and after one month follow up his creatinine level went down to $1.2 \mathrm{mg} / \mathrm{dl}$ with all clinical and laboratory parameter within normal range.

Case-2: A 43 year old businessman from Patuakhali was reffered to Dhaka Medical College Hospital $(\mathrm{DMCH})$ for renal failure. His family members narrated him for severe body ache following recent history of physical assault, there after he was treated by the local physician with NSAIDs. Though his pain was improved, 2 days later he noticed reduced volume of urine and became confused and then admitted to $\mathrm{DMCH}$. There was no history of fever, joint pain and previous use of nephrotoxic drugs. On examination GCS-13 and BP 150/80 mmHg, oedema mild, no rash in the body. 24 hours urine output was $40 \mathrm{ml}$ only which was high coloured. Investigations showed serum creatinine was $9 \mathrm{mg} / \mathrm{dl}$, urine dip stick test was positive for blood but urine routine examination revealed no Red Blood Cell (RBC) with albumin $1+$. serum calcium- $2 \mathrm{mmol} / \mathrm{l}$, serum phosphate- $1.5 \mathrm{mmol} / \mathrm{l}$, urea- $94 \mathrm{mg} / \mathrm{dl}$, serum potassium $-6 \mathrm{mmol} / \mathrm{dl}$, serum bicarbonate- $12 \mathrm{mmol} / \mathrm{dl}$, creatinine kinase-11800 u/l. Patient was treated with several session of $H D$ and his urine output returned to normal after 10 days. He was discharged with Serum Creatinine 2.1 and after one and half months of follow up that was $1.2 \mathrm{mg} / \mathrm{dl}$.

1. Dr. Tania Mahbub, MBBS, MD(Nephrology), Medical Officer, Department of Medicine, Kurmitola General Hospital, Dhaka; 2. Dr. Ferdous Jahan, MBBS, MD (Nephrology), Medical Officer, Department of Medicine, BSMMU, Dhaka; 3. Brig Gen Dewan Masudul Haque(Rtd), MBBS, MPH, Ex Professor and Head, Department of Community Medicine, AFMC, Dhaka; 4. Professor Md. Nizam Uddin Chowdhury, MBBS, MD(Nephrology), ISN Fellow, Dhaka Medical College and Hospital, Dhaka. 
Case-3: A 23 year truck driver from Tongi, admitted to emergency department of Dhaka Medical College Hospital after sustaining a violent road traffic accident associated with drowning in mud water for prolonged time up to the level of neck. After initial resuscitations he was treated for severe muscle injury and fracture in his leg bone conservatively also, wound debridement was done in the department of Orthopaedics in $\mathrm{DMCH}$ as well. Baseline investigations were normal other than a fracture in left fibula. After receiving adequate treatment patient's condition was deteriorated with progressive breathlessness and generalized swelling of the whole body and decreased urine output which was cola coloured. He was found to have serum creatinine- $11 \mathrm{mg} / \mathrm{dl}$ and was referred to dept of Nephrology for evaluation and treatment of his impaired renal function. On examination there were multiple bruises and ecchymosis and some lacerated injury over his left leg and arm. Patient was confused, GCS 8, CK was -17650 u/L, urine dipstick test was positive for blood, urine routine examinations showed few granular casts, albumin $1+$, pus cell $3 / \mathrm{HPF}$. Serum potassium $-5.6 \mathrm{mmol} / \mathrm{l}$, bicarbonate- $14 \mathrm{mmol} / \mathrm{l}$, serum calcium- $1.9 \mathrm{mmol} / \mathrm{l}$, serum phosphate- $1.4 \mathrm{mmol} / \mathrm{l}$, urea-103 $\mathrm{mg} / \mathrm{dl}$. Patient received several session of dialysis. His urine output became normal within 10 days of starting dialysis and returned home after 14 days with full recovery of renal function. At discharge his serum creatinine was $1.2 \mathrm{mg} / \mathrm{dl}$ and after a month it was $0.8 \mathrm{mg} / \mathrm{dl}$.

\section{Discussion}

Rhabdomyolysis is a common clinical condition resulting from a wide variety of physical and nonphysical causes. Most common causes are trauma that occurs in accidents or assault. Others result from strenuous exercise, status epilepticus, delirium tremens, high voltage electrical injury and hyperthermia. Various myopathics, myositis, electrolyte imbalances and systemic infections like toxic shock syndrome, falciparum malaria, leptospirosis and legionellosis are among the nonphysical causes which contribute to rhabdomyolysis ${ }^{2,3}$. Rhabdomyolysis can results from envanomation also, there were some reports that bee sting could be one of important causes of renal failure due to rhabdomyolysis ${ }^{4,5}$. Strenuous muscular exercise causes myolysis especially in untrained individuals and in individuals exercising in hot and humid conditions. It is also very well known that heat stress as in malignant hyperthermia causes myolysis. However, its occurrence secondary to cold stresses in near-drowning is not a very well described entity. In a patient who is nearly drowning, excessive exhaustion against water for survival causes myolysis, further compounded by the muscular hypoperfusion. Besides, alveolar hypoperfusion from water inhalation induces lactic acidosis which promotes muscle cell lysis leading to myoglobinuria, hyperkalaemia and hyperuricaemia ${ }^{6}$. Myoglobin released from damaged muscles is directly toxic to the renal tubular epithelial cells. It also induces intratubular cast formation which is enhanced in the presence of hypovolemia and acidosis. However, rhabdomyolysis is not the only cause of acute renal failure in near drowning. In a study of 30 patients of near drowning, Spicer et al ${ }^{7}$ identified nearly 50\% patients with acute renal insufficiency, the causes was hypovolemia, shock and multisystem failure, rhabdomyolysis and isolated acute renal insufficiency ${ }^{7}$. While the majority had mild reversible elevation in serum creatinine, $7 \%$ had severe ARF requiring dialysis. Renin angiotensin surge while returning to dry land after whole body immersion may be contributory to the predominant renal injury in such patients ${ }^{8}$.

\section{Conclusion}

Rhabdomyolyisis is not an uncommon condition. It can present due to a wide variety of causes and a life threatening but a completely curable condition. Depending on severity of renal impairment some patient may need long term dialysis support whereas others might respond to hydration and conservative therapy only. Therefore, early diagnosis and prompt referral to appropriate center is crucial to save life.

\section{References}

1. Paul J, Scheel J, Choi M. Acute Renal Failure: Rhabdomyolysis. Oxford Handbook of Nephrology and Hypertension 2008;138-9.

2. Visweswaran P. Guntupalli J. Rhabdomyolysis. Critical Care Clinics 1999; 15:415-26.

3. Holder RV, Sever MS, Erek $E$ et al. Rhabdomyolysis. J Am SocNephrol 2000;11:1553-61. 
4 Hiran S, Pande TK, Pani S et al. Rhabdomyolysis due to multiple honey bee stings: Postgrad Med J 1994 December; 70(830):937.

5. Enviado a Revisar. Acute renal failure due to multiple stings by Africanized bees: Report on 43 cases. Nephrologia 2010; 30(5):531-8.

6. Agar JWM. Rhabdomyolysis and acute renal failure after near drowning cold salt water: Med J Aust 1999;161:686-7.
7. Spicer ST, Quinn D, Nyein N et al. Acute renal impairment after immersion and near-drowning: J Am Soc Nephrol 1999; 10:382-6.

8. Haddad LM, Shannon MW and Winchester JF. Toxic marine life: Clinical management of poisoning and drug overdose. 3rd Ed. WB Saunders Company. Philadelphia, 1998:386-99. 